\title{
SCIENCE IN FRANCE-A REPORT BY OECD
}

France's scientific achievements are falling short of her intentions, according to a study which has been carried out by the Organisation for Economic Co-operation and Development (OECD, Reviews of National Science Policy: France, 1966). The report is one of a series of studies of science policy in member nations of the OECD. The examiners were Dr. A. H. Haley of the University of Oxford, Professor H. Johnson of the University of Chicago, Professor G. B. Kistiakowsky of Harvard University, and Dr. L. Morandi, vice-president of the Montecatini Company. The survey holds that France, where science planning since 1958 has worked towards an overall concept of science policy and coordinated national options, may be losing her courage. Its authors point to the fact that the Committee of Ministers, which is responsible for coordinating science policy, has met on an average only once a year since 1961 and that it has had a progressively weakening influence on the budget "since the number of decisions in the scientific sphere left to the decision of the Prime Minister is steadily increasing from year to year". As further evidence, they note that the major options such as the construction of the Concorde aircraft, the development of the Pierelatte programme for gaseous diffusion and the nuclear developments at Chinon were undertaken without consulting the central agencies responsible for advising the government on science policy, and, finally, that even where definite targets had been put forward in the IVth Plan, it has been reported that only 79.7 per cent of these targets have been reached. The report concludes that, while this may just be a temporary lull between conception and implementation of a unified policy, there is some fear that the government is afraid to take the plunge and commit itself completely.

The report traces science policy in France from tentative beginnings in the late thirties, when the Under-secretariat of State for Scientific Research and the National Centre for Scientific Research were established, through the post-war expansion with new agencies for atomic research, aeronautics, health and agriculture. Until the early fifties France was content to remain dependent on foreign technology. Since then France has moved ahead rapidly on research expenditure-the government alone spent 1,073 million francs in 1965 against 249 million in 1959 and the gross expenditure on research and development in all sectors came to 6,248 million francs, or 1.6 per cent of the gross national product, in 1963. This is still below the corresponding GNP figures for Britain and, of course, the United States (where the percentages of GNP were $2 \cdot 2$ and $3 \cdot 1$, respectively, in 1962), but France is spending far less on defence research; in 1962 only 37.5 per cent of government research expenditure went to the armed forces compared with more than 60 per cent in the two other countries.

France is breaking into space and atomic energy in a big way. She has allocated 33 per cent of her scientific expenditure to these two fields in which the United States is investing only 29 per cent in atomic and space research and the National Science Foundation. Another interesting aspect of the French budget for research is the 19.5 per cent spent on national education, primarily for research in the universities and other higher scientific establishments such as the École Normale Supérieure. Of course, in the United States many of the grants for university research are made by the National Science Foundation, the National Institutes of Health and the various branches of the Department of Defense, but the universities still account for only 12 per cent of the basic research in the United States, with $\mathbf{7 4}$ per cent originating in private firms (over 40 per cent of the costs are met by the govern- ment, however). In France, 47 per cent of the research was carried out by private firms, with the government meeting half the costs.

The first formal attempt to integrate scientific and political objectives took place in France when the IVth Economic and Social Development Plan was being prepared (1962-1965). Since 1965 the ministry in charge of scientific research and responsible to the joint secretariat of the two science committees-the General Delegation for Scientific and Technical Research-has been replaced on the political side by a Secretariat of State for Scientific Research and Atomic and Space Questions and on the scientific side by a Delegate-General for Scientific and Technical Research to work in liaison with the Commissaire Général du Plan. This increasing emphasis on central control by the General Delegation and its Secretariat and various committees, coupled with a recog. nition of the importance of science to all economic and political questions, is still unique to France.

The examiners, like all those concerned with the role of science, welcome the development, but also express the fear that some scientific decisions are being made for political rather than economic reasons. They applaud the desire to increase contributions to international research efforts, but do not feel that France can afford a policy of "going it alone" in prestige areas of science; they are afraid that in practice there is not yet a realistic dialogue between statesmen and scientists, in which case "there is a fear that considerable sums may be spent without research deriving the full benefit".

The examiners found educational policy to be also more indicative than active-the government has not yet worked out a general policy for training senior scientific staff nor has it developed a concerted plan for technical training. As for the training of engineers and scientists, the examiners question the early specialization required by the baccalaureat and the dual stream of university-level education offered by the universities and the Grandes Écoles. When the Grandes Ecoles - such as the Eifole Normale Supérieure and the Ecole Polytechnique-were founded about 1900, they filled the need for engineering training that was not met by the universities. But though they are still the most influential science schools in the country, the study does not feel that they have changed sufficiently to meet the increasing need for researchers and teachers in France. About 20 engineering schools are regarded as Grandes Écoles and take roughly 1,500 first-year students or about 20 per cent of the intake of all engineering schools. But more than twice as many as this have studied for two or three years to gain a place, thereby forgoing admission to university. Another complaint of the examiners is the emphasis in the Grandes Écoles on engineering and administration rather than research.

In contrast to the continuing pressure for admission to the Grandes Ecoles, the universities are finding it more and more difficult to attract able young scientists; many places are left vacant for lack of candidates. The examiners would like to see closer cooperation between the universities and the Grandes $E^{\prime}$ coles to make it easier to transfer from one type of institution to the other and to enable engineering graduates to do postgraduate research at university.

In all areas of science policy, the examiners feel that the gap must be filled between "the remarkable effort being made to rationalize the preparation of decisions affecting both science and the economy, and the universal tendency to choose certain scientific objectives for political reasons without always realizing their economic implications". 